\section{Production of Salicylic Acid in Tobacco and Cowpea Plants by a Systemic Fungicide Ferimzone and Induction of Resistance to Virus Infection}

\author{
Masaharu NaKayama, Kazuho MatsuURA \\ and Tetsuro OKUNO* \\ Agricultural Research Laboratories, Agro Division, Takeda \\ Chemical Industries, Ltd., Wadai, Tsukuba 300-42, Japan \\ * Laboratory of Plant Pathology, Faculty of Agriculture, Kyoto \\ University, Sakyo-ku, Kyoto 606-01, Japan
}

(Received June 19, 1995 ; Accepted October 9, 1995)

\section{INTRODUCTION}

Plants have a number of defense mechanisms against pathogen attacks. In addition to a cultivar-race specific resistance, plants can acquire local and systemic resistance following infection with various pathogens which induce necrotic lesions. ${ }^{1,2)}$ Systemic acquired resistance (SAR) is effective to a wide range of plant pathogens including fungi, bacteria and viruse ${ }^{3,4)}$ and it also can be induced by chemicals such as salicylic acid (SA) and its derivatives, ${ }^{5-7)}$ 2,6dichloroisonicotinic acid (INA) ${ }^{8)}$ and 7-methoxycarbonyl benzo-1, 2, 3-thiadiazol ${ }^{9)}$ that have no antimicrobial activity in vitro. Although it remains to be investigated how these chemicals are involved in SAR, infection with necrotizing pathogens increase endogenous SA levels in plants. Recent reports suggest that $\mathrm{SA}$ serves as an endogenous signal molecule required for the induction of SAR. ${ }^{10-12)}$

Ferimzone, (Z)-2'-methylacetophenone 4,6-dimethylpyrimidin-2-ylhydrazone (Fig. 1) is a novel systemic fungicide developed for the control of rice diseases and exhibits strong antifungal activity against many plant-pathogenic fungi including Pyricularia oryzae both in vitro and in vivo. ${ }^{13-15)}$ Since ferimzone was found to be effective for the control of some bacterial diseases in a field, ${ }^{16)}$ it has been tempting to test whether this chemical has SAR inducing

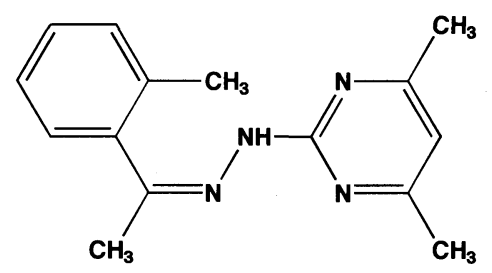

Fig. 1 Chemical structure of ferimzone. activity or not. We report here that spraying tobacco and cowpea plants with ferimzone induced acquired resistance to infection with tobacco mosaic virus (TMV) and cucumber mosaic virus (CMV), respectively, and that the treatment with ferimzone significantly increased the amount of endogenous $\mathrm{SA}$ in both tobacco and cowpea plants.

\section{MATERIALS AND METHODS}

\section{Plants}

Tobacco (Nicotiana tabacum L. cv. Samsun NN) and cowpea (Vigna unguiculata L. cv. Sanjakusasage) were grown in a plastic pot containing soil in a greenhouse at $25^{\circ} \mathrm{C}$ under natural day light.

\section{Chemicals}

Ferimzone (technical grade containing $Z$-isomer of more than 97.0\%) was used throughout all the experiments. The compound was dissolved in ethanol and diluted with deionized water to make ethanol concentration less than $1 \%$ in a final solution. SA was dissolved in deionized water by adjusting $\mathrm{pH}$ to 7 with $\mathrm{NaOH}$.

\section{Viruses}

TMV (OM strain) and CMV (Y strain) were propagated in N. tabacum L. cv. Bright Yellow and cv. Samsun NN, respectively and purified using the method described by Takanami \& Tomaru. ${ }^{17)}$

\section{Extraction and Analysis of Salicylic Acid}

Endogenous SA was extracted from tobacco and cowpea leaves sprayed with ferimzone. Leaves $(1 \mathrm{~g})$ were sliced, rolled into the bottom of test tubes and soaked with $10 \mathrm{ml}$ of $2 \%$ acetic acid. The solution was boiled for $10 \mathrm{~min}$ and centrifuged for $10 \mathrm{~min}$ at $1000 \times g$, and the supernatants were used to assess the amount of SA in leaves. The SA extract was injected onto a C-18 column (II 5C18-HG, Wako Pure Chemical Industries, Ltd.) equilibrated with $50 \%$ aqueous methanol (v/v) containing $0.05 \%$ phosphoric acid and eluted at $1 \mathrm{ml} / \mathrm{min}$. The peak of free $\mathrm{SA}$ was detected with a fluorescent detector (excitation $290 \mathrm{~nm}$, emission $402 \mathrm{~nm}$ ).

\section{Virus Infection Assay}

Two month-old tobacco plants at 6 to 8 leaf stage and 7 day-old cowpea plants were sprayed with ferimzone at the concentrations of 50 and $500 \mu \mathrm{M}$, with SA at the concentrations of 5 and $10 \mathrm{mM}$, or with water. All plant leaves were washed with tap water at the following day. Leaves of the plants were inoculated with TMV at the concentration of 0.2 $\mu \mathrm{g} / \mathrm{ml}$ or $\mathrm{CMV}$ at the concentration of $3 \mu \mathrm{g} / \mathrm{ml}, 1,4$ and 7 days after chemical treatment. The number of local lesions was counted 3 days after inoculation. 

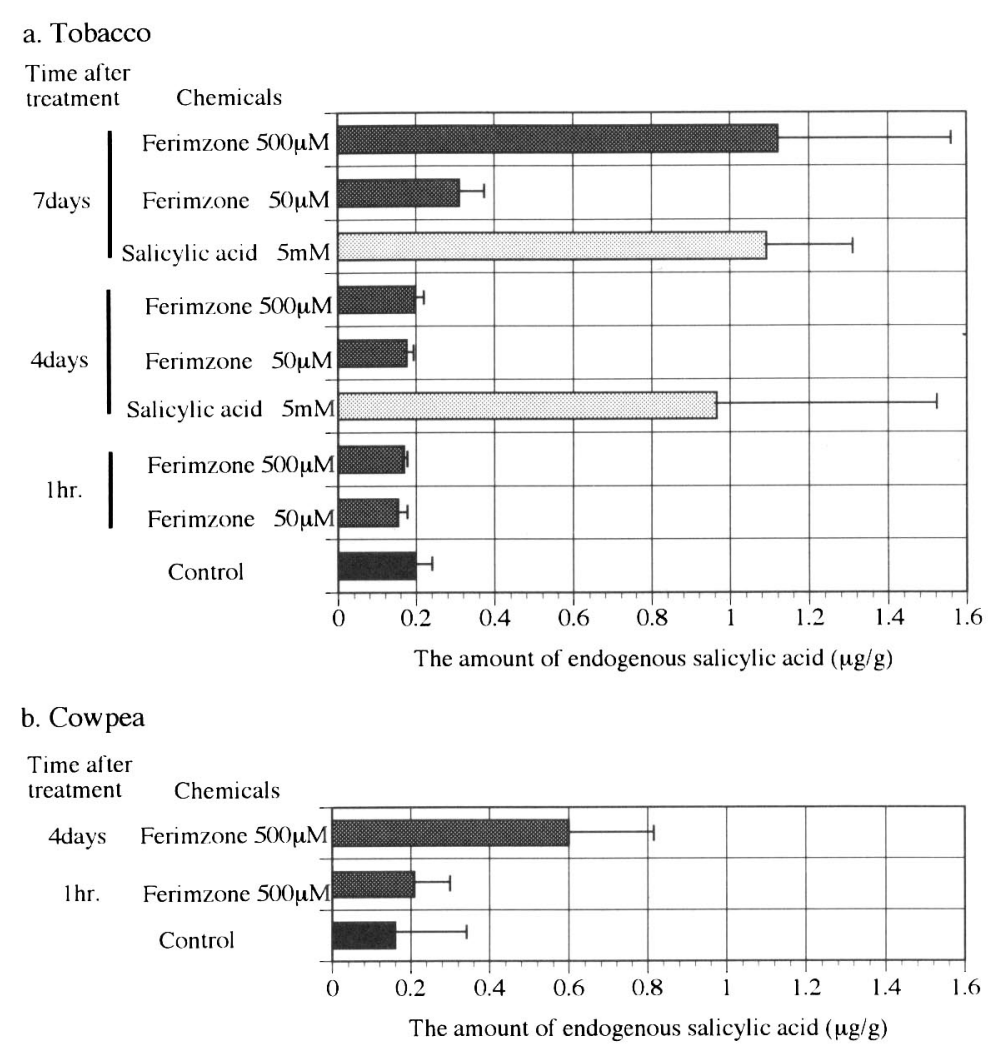

Fig. 2 The quantitative analysis of endogeneous salicylic acid extracted from leaves treated with ferimzone or salicylic acid. The means of amounts of endogeneous salicylic acid in 9 leaves from tobacco plants and 6 to 8 leaves from cowpea plants were calculated, respectively. Error bars show significative limits $(p=5 \%)$ with the Tukey compromise test.

\section{RESULTS AND DISCUSSION}

In tobacco leaves at 7 days and in cowpea leaves at 4 days after ferimzone treatment at the concentration of $500 \mu \mathrm{M}$, the amount of endogenous SA increased by 3 to 4 folds compared to water treated controls and it was comparable to that in leaves sprayed with SA at the concentration of $5 \mathrm{~mm}$ (Fig. 2). No significant differences in the amount of endogenous SA were observed between ferimzone-treated and water-treated leaves in both tobacco sampled 4 days and cowpea sampled $1 \mathrm{hr}$ after the treatment. Ferimzone at the concentration of $50 \mu \mathrm{M}$ did not significantly influence the amount of endogenous SA in tobacco plants.

Ferimzone was tested for the ability to influence local lesion formation by TMV on tobacco leaves by spraying at the concentration of $500 \mu \mathrm{M}$. The number of local lesions on either sprayed or unsprayed upper leaves significantly decreased compared to the water-treated controls when the leaves were inoculated with TMV 7 days after the treatment (Table 1, Expts. 1 and 2). However, no significant differences in the number of local lesions were observed between ferimzone-treated and water-treated leaves inoculated $4 \mathrm{hr}$ and 1 day after the treatment (Table 1, Expts. 1 and 2). Similar results were obtained by spraying SA at the concentration of $5 \mathrm{~mm}$ (Table 1, Expt. 1). Significant reduction in the number of local lesion caused by CMV infection was also observed in cowpea leaves pretreated with ferimzone and SA (Table 1, Expts. 3 and 4). Ferimzone and SA at the concentrations up to $500 \mu \mathrm{M}$ and $5 \mathrm{mM}$ did not cause any visible damage on leaves of tobacco or cowpea plants. However, when ferimzone and SA were applied at higher concentrations of 1 and $10 \mathrm{~mm}$, respectively, they sometimes incited small necrosis spots on tobacco and cowpea leaves. Ferimzone caused severe necrosis and deterioration of leaves in tobacco at the concentrations higher than $5 \mathrm{~mm}$.

The results presented in this report showed the ability of ferimzone to induce resistance against virus infection in both tobacco and cowpea plants several days after spray treatment. Since metabolic products of ferimzone in higher plants do not contain any signal molecules reported so far in reference to the activation of plant defense responses, we consider that ferimzone in itself has the ability to induce virus resistance in plants. ${ }^{18)}$ Much evidence has indicated that endogenous SA is involved in the activation of plant defense responses including virus resistance. ${ }^{10-12)} \mathrm{SA}$ whose amount is increased in ferimzone-treated plants is likely responsible for the induction of virus resistance by ferimzone. Involvement of the metabolic products of ferimzone could not be excluded for the induction of endogenous SA in plants.

Ferimzone was originally developed for the control of 
Table 1 The effect of ferimzone on local lesion formation by TMV and CMV in tobacco and cowpea leaves. ${ }^{\text {a) }}$

\begin{tabular}{|c|c|c|c|c|c|c|c|c|}
\hline Expt. & Plant/Virus & $\begin{array}{c}\text { Leaf } \\
\text { position }\end{array}$ & $\begin{array}{c}\text { Time between } \\
\text { treatment and } \\
\text { inoculation }\end{array}$ & Chemical & concentration & $\begin{array}{l}\text { Average number } \\
\text { of lesions }{ }^{\text {b) }}\end{array}$ & & $\%$ protection \\
\hline \multirow[t]{6}{*}{1} & \multirow{6}{*}{$\begin{array}{l}\text { Tobacco } \\
\text { /TMV }\end{array}$} & Sprayed & $4 \mathrm{hr}$ & $500 \mu \mathrm{M}$ & Ferimzone & $117 \pm 16$ & & \\
\hline & & & & $5 \mathrm{~mm}$ & Salicylic acid & $91 \pm 11$ & & \\
\hline & & & & & Control & $128 \pm 20$ & NS & \\
\hline & & Sprayed & 7 days & $500 \mu \mathrm{M}$ & Ferimzone & $34 \pm 7$ & $\mathrm{a}$ & 58 \\
\hline & & & & $5 \mathrm{~mm}$ & Salicylic acid & $34 \pm 3$ & a & 58 \\
\hline & & & & & Control & $80 \pm 10$ & $b$ & \\
\hline \multirow[t]{8}{*}{2} & \multirow{8}{*}{$\begin{array}{l}\text { Tobacco } \\
\text { /TMV }\end{array}$} & Sprayed & 1 day & $500 \mu \mathrm{M}$ & Ferimzone & $43 \pm 4$ & & \\
\hline & & & & & Control & $71 \pm 16$ & NS & \\
\hline & & Unsprayed & 1 day & $500 \mu \mathrm{M}$ & Ferimzone & $64 \pm 19$ & & \\
\hline & & upper & & & Control & $61 \pm 5$ & NS & \\
\hline & & Sprayed & 7 days & $500 \mu \mathrm{M}$ & Ferimzone & $13 \pm 3$ & $\mathrm{a}$ & 65 \\
\hline & & & & & Control & $37 \pm 4$ & $\mathrm{~b}$ & \\
\hline & & Unsprayed & 7 days & $500 \mu \mathrm{M}$ & Ferimzone & $20 \pm 1$ & $\mathrm{a}$ & 66 \\
\hline & & upper & & & Control & $59 \pm 12$ & $\mathrm{~b}$ & \\
\hline \multirow[t]{6}{*}{3} & \multirow{6}{*}{$\begin{array}{l}\text { Cowpea } \\
\text { /CMV }\end{array}$} & Sprayed & 4 days & $500 \mu \mathrm{M}$ & Ferimzone & $74 \pm 21$ & $\mathrm{a}$ & 88 \\
\hline & & & & $10 \mathrm{~mm}$ & Salicylic acid & $135 \pm 46$ & $a b$ & 79 \\
\hline & & & & & Control & $634 \pm 122$ & $\mathrm{c}$ & \\
\hline & & Sprayed & 7 days & $500 \mu \mathrm{M}$ & Ferimzone & $13 \pm 5$ & $\mathrm{a}$ & 82 \\
\hline & & & & $10 \mathrm{mM}$ & Salicylic acid & $27 \pm 5$ & $a b$ & 62 \\
\hline & & & & & Control & $71 \pm 11$ & $\mathrm{c}$ & \\
\hline \multirow[t]{3}{*}{4} & \multirow{3}{*}{$\begin{array}{l}\text { Cowpea } \\
\text { /CMV }\end{array}$} & Sprayed & 4 days & $50 \mu \mathrm{M}$ & Ferimzone & $99 \pm 12$ & $\mathrm{a}$ & 65 \\
\hline & & & & $5 \mathrm{~mm}$ & Salicylic acid & $213 \pm 34$ & $a b$ & 24 \\
\hline & & & & & Control & $279 \pm 76$ & $\mathrm{~b}$ & \\
\hline
\end{tabular}

a) Leaves were inoculated with TMV $(0.2 \mu \mathrm{g} / \mathrm{ml})$ or CMV $(3 \mu \mathrm{g} / \mathrm{ml})$ at indicated time after chemical treatment.

b) Mean values per leaf from 8 to 20 tobacco leaves are presented in the experiments 1 and 2 . Mean values per 2 primary leaves from 8 cowpea plants are presented in the experiments 3 and 4.

Figures with the same letter are not significantly different $(p=5 \%)$ according to Tukey compromise test. NS : not significant.

fungal diseases and has wide antifungal spectrum in vitro, ${ }^{14,15,18)}$ but has little antibacterial activity in vitro. The observed control activity of ferimzone in some bacterial diseases in field rice plants ${ }^{16)}$ might be explained by the ability of ferimzone to induce resistance response in plants reported here although there have been no report for the involvement of SA in defense response in rice plants. Ferimzone in itself or unknown substances including metabolites of ferimzone may function as a signal molecule for the induction of bacterial resistance in rice plants. We cannot exclude the possibility of the involvement of SA as a signal molecule in the induction of resistance in rice plants. The present results indicate that ferimzone has a property of resistance inducing chemical like INA in addition to the original fungicide activity. ${ }^{8)}$ Consequently, ferimzone may be used as a resistance inducing chemical to protect crops against fungal, bacterial and viral diseases.

\section{ACKNOWLEDGMENTS}

The authors wish to thank Dr. W. Miyagawa for his technical advice in the analysis of salicylic acid, and Ms. Y. SuzukiKajihara for her technical assistance. This research was supported in part by financial aid from the Pesticide Industries Association of Japan.

\section{REFERENCES}

1) L. Sequeira : Annu. Rev. Microbiol. 37, 51 (1983)

2) S. Tuzun, M. N. Rao, U. Vogeli, C. L. Schardl \& J. Kuc: Phytopathology 79, 979 (1989)

3) L. C. Van Loon: Physiol. Plant Pathol. 6, 289 (1975)

4) S. Gianinazzi \& P. Ahl : J. Plant Pathol. 89, 275 (1983)

5) R. F. White: Virology 99, 410 (1979)

6) L. C. Van Loon \& J. F. Antoniw: Neth. J. Plant Pathol. 88, 237 (1982)

7) E. R. Ward, S. J. Uknes, S. C. Williams, S. S. Dincher, D. L. Wiederhold, D. C. Alexander, P. Ahl-Goy, J. P. Metraux \& J. A. Ryals : Plant Cell 3, 1085 (1991)

8) J. P. Metraux, P. Ahl-Goy, T. Staub, J. Speich, A. Steinemann, J. Ryals \& E. Ward : "Advances in Molecular Genetics of Plant-Microbe Interactions," ed. by H. Hennecke \& D. P. S. Verma, Vol. 1, Kluwer Academic Publishers, Dordrecht, pp. 432-439, 1991

9) T. Okuno, M. Nakayama, N. Okajima \& I. Furusawa : Ann. Phytopathol. Soc. Jpn. 57, 203 (1991)

10) I. Raskin : Annu. Rev. Plant Physiol. Plant Mol. Biol. 43, 439 (1992)

11) J. Malamy, J. P. Carr, D. F. Klessig \& I. Raskin : Science 250, 1002 (1990)

12) J. P. Metraux, H. Signer, J. Ryals, E. Ward, M. Wyss-Benz, 
J. Gaudin, K. Raschdorf, E. Schmid, W. Blum \& B. Inverardi : Science 250, 1004 (1990)

13) K. Matsuura, T. Okuno, Y. Kitamura, R. Ishikawa, Y. Ishida \& K. Konishi : Abstr. ; 5th Int. Congr. Plant Pathol., Kyoto, p. 306, 1988

14) T. Okuno, I. Furusawa, K. Matsuura \& J. Shishiyama : Ann. Phytopathol. Soc. Jpn. 55, 281 (1989)

15) T. Okuno, I. Furusawa, K. Matsuura \& J. Shishiyama: Phytopathology 79, 827 (1989)

16) J. Kato: "Annual Report of General Entrusted Tests," Vol. IV in Kanto, Tozan and Tokai Areas, Jpn. Plant Prot. Assoc., Tokyo, p. 169, 1994.

17) Y. Takanami \& K. Tomaru: Virology 37, 293 (1969)

18) K. Matsuura, Y. Ishida, T. Kuragano \& K. Konishi : $J$. Pesticide Sci. 19, S197 (1994)

\section{要 約}

浸透性殺菌剈フェリムゾンによるサリチル酸はウイル ス感染に対する抵抗性誘導能をもつ

中山政治，松浦一穂，奥野哲郎

フェリムゾン, $(Z)$-2'-methylacetophenone 4, 6-dimethylpyrimidin-2-ylhydrazone を夕バコおよびササゲに処理した際には, 内 在性サリチル酸量の増加が認められた。 そこで，フェリムゾン 処理を行なった植物に, 夕バコモザイクウイルス (TMV), ある いは，キュウリモザイクウイルス (CMV) の接種を行なったと ころ,サリチル酸処理の場合と同様な局部獲得抵抗性を示した. さらに, 夕バコの場合は TMV 接種に対して全身獲得抵抗性が 確認された。 これらの抵抗性は, それぞれの植物に対する $\mathrm{TMV}$ ，あるいは，CMV 接種による局部病斑の $50 \%$ 以上の減少 として観察された.フェリムゾンは植物体に内在性サリチル酸 を誘導する作用性があり, フェリムゾン処理された植物体はこ の内在性サリチル酸量の増加によって抵抗性を獲得することが 示唆された。 